\title{
Covid-19 among the population deprived of liberty in Brazil and in the state of
}

\section{Paraná}

\author{
Covid-19 na população privada de liberdade do Brasil e do estado do Paraná \\ Covid-19 en la población detenida del Brasil y del estado del Paraná
}

\author{
Gabriela Caetano Lopes Martins \\ ORCID: https://orcid.org/0000-0002-3027-4251 \\ Universidade Federal do Paraná, Brazil \\ E-mail: gclmartins@icloud.com \\ Camila Barreto Araujo \\ ORCID: https://orcid.org/0000-0001-8955-0022 \\ Universidade Federal do Paraná, Brazil \\ E-mail: camila.b.araujo@hotmail.com \\ Bárbara Vieira Sardi \\ ORCID: https://orcid.org/0000-0003-2084-4799 \\ Universidade Federal do Paraná, Brazil \\ E-mail: babe.vs@hotmail.com \\ Rafael Gomes Ditterich \\ ORCID: https://orcid.org/0000-0001-8940-1836 \\ Universidade Federal do Paraná, Brazil \\ E-mail: prof.rafaelgd@gmail.com \\ Francisco Boçon Junior \\ ORCID: https://orcid.org/0000-0001-5233-4596 \\ Universidade Federal do Paraná, Brazil \\ E-mail: franciscoboconjr@gmail.com \\ William Augusto Gomes de Oliveira Bellani \\ ORCID: https://orcid.org/0000-0002-1429-616X \\ Faculdade Pequeno Príncipe, Brazil \\ E-mail: william.bellani@gmail.com
}

\begin{abstract}
The aim of this study was to compare Covid-19 incidence and mortality among population deprived of liberty (PDL), prison staff and general population in Brazil and in the state of Paraná. The methods consisted in data collection from weekly reports from the Nacional Justice Board and Health Ministry, between June and December 2020. Covid-19 testing, infection, mortality, and lethality rates were compared among PDL, prison staff and Brazil and Paraná's general population. As for the results, compared to the general population, the relative risk of Covid-19 confirmed case among PDL was 1.594 (CI 95\% 1.578 - 1.610) in Brazil and 3.055 (CI 95\% 2.941 - 3.173) in Paraná. The proportion of test per national population was $22.86 \%, 44.42 \%$ and $4.45 \%$ among PDL, prison staff and general population, respectively. In Paraná, the testing rate was $8.19 \%$ in PDL, $42.98 \%$ in prison staff and $12.70 \%$ in the general population. In conclusion, the proportion of Covid-19 cases is greater in prisons than in the general population and the testing of PDL should be amplified.
\end{abstract}

Keywords: COVID-19; Coronavirus Infections; Public health; Prisioners.

\section{Resumo}

O objetivo do presente estudo foi comparar a incidência e a mortalidade por Covid-19 entre a população privada de liberdade (PPL), os servidores do sistema carcerário e a população em geral do Brasil e do estado do Paraná. Quanto a metodologia, foi realizado um estudo ecológico com coleta de dados a partir de boletins semanais realizados pelo Conselho Nacional de Justiça e pelo Ministério da Saúde, entre junho e dezembro de 2020. Foram comparadas taxas de testagem, de infecção, de mortalidade e de letalidade por Covid-19 entre a PPL, servidores e a população em geral do Brasil e do Paraná. Como resultados, o risco relativo de caso confirmado de Covid-19 pela PPL em comparação com a população em geral foi de 1,594 (IC 95\% 1,578 - 1,610) no Brasil e de 3,055 (IC 95\% 2,941 - 3,173) no Paraná. A proporção teste/população nacional foi de 22,68\%, 44,24\% e 4,45\% entre PPL, servidores e população em geral, respectivamente. No Paraná a taxa de testagem foi de $8,19 \%$ na PPL, $42,98 \%$ nos servidores e $12,70 \%$ na população em geral. Conclui-se que a proporção de casos confirmados de Covid-19 é maior entre a população carcerária do que na população em geral e que a testagem da PPL deve ser ampliada.

Palavras-chave: COVID-19; Infecções por Coronavírus; Saúde pública; Prisioneiros. 


\section{Resumen}

El objetivo del presente estudio fue comparar la incidencia et la mortalidad de la Covid-19 entre la población detenida, los funcionarios de la cárcel et la población en general del Brasil et del Paraná. Por la metodología, fue realizado un estudio ecológico con recolección de datos de boletines semanales del Consejo Nacional de Justicia et del Ministerio de la Salud, entre junio et diciembre de 2020. Fueron comparadas las tajas de testeo, infección, mortalidad et letalidad entre detenidos, funcionarios de la cárcel et la población general del Brasil et del Paraná. Como resultados, el risco relativo de caso confirmado de Covid-19 pela población detenida en comparación con la población general fue de 1,594 (IC 95\% 1,578 - 1,610) en el Brasil et de 3,055 (IC 95\% 2,941 - 3,173) en el Paraná. La proporción de testes/populación fue de 22,86\%, 44,42\% et 4,45\% entre detenidos, funcionarios et población general, respectivamente. En el Paraná, la taja de testeo fue de 8,19\% en los detenidos, 42,98\% en los funcionarios et 12,70\% en la población general. En conclusión, la proporción de casos confirmados de la Covid-19 es más grande entre la población detenida que entre la población general et el testeo de los detenidos debe ser ampliado.

Palabras clave: COVID-19; Infecciones por Coronavirus; Salud pública; Prisioneros.

\section{Introduction}

The Covid-19, disease triggered by the new Sars-Cov-2 virus, brought about a global pandemic that began in 2020, with millions of human lives lost and catastrophic repercussions (Khan, et al., 2020). One of the most vulnerable populations to the disease is the population deprived of liberty (PDL) (Khan, et al., 2020) (Saloner, et al., 2020).

Prisons are at-risk locations for the spread of Covid-19 due to factors such as overcrowding. More than half of the world's prisons have occupancy rates that exceed the maximum capacity (WPB, 2021). This is the case of Brazil, which has the third largest prison population in the world, with more than 760,000 people. Until December 2019, the occupation rate of the Brazilian prison system was of 169\% (CNMP, 2018) (CNMP, 2019).

Overcrowding makes it impossible to adopt social distancing measures (Meyer, et al., 2020). In addition, PDL and prison staff frequently come and go from the institution and there is no structure to contain major outbreaks of respiratory diseases or to manage infected patients (Wang; Zenilman \& Brinkley-Rubinstein, 2020). In this context, there is a high prevalence of respiratory viral infections in the prison population (Akiyama; Spaulding \& Rich, 2020) (The Legal Aid Society, 2020). The high transmission rate of Covid-19 in prison institutions also have the potential to influence the broader transmission of the virus to the community, once $55 \%$ of the detainees return to their communities every week, as well as the staff (Njuguna, et al., 2020) (Carvalho; Santos \& Santos, 2020).

Aside from the higher infection rate, inequalities regarding social determinants of health that primarily affect representative groups of the current prison population (such as racial minorities, mental disorders, and substance abuse) lead to concentration of some diseases in PDL (Akiyama; Spaulding \& Rich, 2020). Thus, this population has a higher incidence of risk factors for Covid-19, such as diabetes, hypertension, and heart disease (Wang; Zenilman \& Brinkley-Rubinstein, 2020). In addition, emotional stress, as well as physical and sexual violence are common in prison centers, which can weaken the immune system (Barnert, 2020). Hence, PDL appears to be a population at risk for more severe cases of Covid-19.

Therefore, we understand the impact of the prison population on a country in a time of pandemic. Moreover, there is the disregard for the lives of these individuals, who must have guaranteed their right to health, even though they have lost their freedom. Thus, we hypothesized that the incidence of Covid-19 is higher among PDL than in general population. The objective of this study is to compare the incidence and mortality by Covid-19 between the PDL, the prison staff and the general population of Brazil and the state of Paraná.

\section{Methodology}

This research was approved by a Research Ethics Committee (Certification of Ethical Appreciation Presentation number 32121120.3.3003.5225). We performed an ecological study (aggregated, observational, and transversal) using only official public data. This study design was elected once data was only available at a populational level, rather than individual 
level. Nevertheless, since the purpose of this study is to make large-scale comparisons (between the general population and the PDL) to guide public health strategies, the use of an ecological study is adequate. Hence, for our study, health outcomes are aggregates of individual heath data available in official public data from the Brazilian National Justice Council (NJC) and the Brazilian Ministry of Health.

Data referring to the number of Covid-19 confirmed cases, deaths, and RT-PCR tests performed at the Brazilian and Paraná prison system were collected from the Brazilian NJC weekly reports. We collected data from the PDL and prison staff, from both Brazil and Paraná. The analysis period was from June 15, 2020 (date of the first published report) to December 23, 2020 (date of the last report of 2020). The number of cases was reported cumulatively, including active and recovered cases and deaths.

To compare with the general population, data from the Brazilian Ministry of Health weekly epidemiological reports were used, from June 14, 2020, to December 26, 2020. We collected data on the number of deaths and confirmed cases in Brazil and Paraná in each epidemiological week of the period of interest, as well as the number of tests performed during the mentioned period.

The following rates were then calculated: confirmed Covid-19 cases, mortality, and lethality, testing rate and the proportion of positive tests results. The rates were calculated separately for each population of the study (PDL, prison staff and general population), and for each territorial coverage (Brazil and Paraná).

The statistical analysis was performed through the Independence Qui-Square test, using the software IBM SPSS Statistics 23®.

\section{Results}

There were 755,274 incarcerated individuals in Brazil and 29,354 in the state of Paraná. The number of prison staff in Brazil was 127,208 and 3,276 in Paraná. During the study period, 41,971 confirmed cases of Covid-19 were reported among the PDL in Brazil and 2,942 in Paraná. Among prison staff, 12,836 cases were confirmed in the country and 545 in Paraná. As for the general population, 7,456,806 cases were confirmed in Brazil and 400,288 in Paraná.

The proportion of confirmed Covid-19 cases in the PDL and prison staff was superior to the general population both in the national and local scene (Tables 1 and 2).

Regarding the lethality, although the elevated number of confirmed cases in the prison system, the death proportion on this population (PDL and prison staff) was smaller than the ones in the general population, both national and locally (Tables 1 and 2).

The number of performed tests revealed disparities between the studied populations: the tests/population rate was smaller in the PDL compared to the prison staff, with a difference superior to $20 \%$ in the national scene and over $30 \%$ in the local scene. At the same time, both PDL and prison staff had the testing proportion superior to the one of Brazil general population. In contrast, the positivity of tests, that is, the rate of confirmed cases/performed tests, was higher in the Brazilian general population, although smaller in the general population of Paraná (Tables 1 and 2). 
Table 1. Brazil: epidemiological data of covid-19 in the prison system and general population in 2020.

\begin{tabular}{lcccccc}
\hline & \multicolumn{2}{c}{ Population Deprived of Liberty } & \multicolumn{2}{c}{ Prison Staff } & \multicolumn{2}{c}{ General Population } \\
\hline & $\%$ & $\mathrm{n} / 1,000$ & $\%$ & $\mathrm{n} / 1,000$ & & $\mathrm{n} / 1,000$ \\
\hline Confirmed Cases* & 5.56 & 55.57 & 10.09 & 100.91 & 3.55 & 35.53 \\
Deaths* & 0.31 & 3.07 & 0.72 & 7.25 & 2.56 & 25.56 \\
Covid-19 Mortality* & 0.02 & 0.2 & 0.07 & 0.7 & 0.09 & 0.9 \\
\hline
\end{tabular}

\begin{tabular}{|c|c|c|c|}
\hline Testing & & & \\
\hline Performed tests* $(\mathrm{n})$ & 171,293 & 56,273 & $9,358,807$ \\
\hline $\begin{array}{l}\text { Tests/ } \\
\text { population* }(\%)\end{array}$ & $22.68 \%$ & $44.24 \%$ & $4.45 \%$ \\
\hline $\begin{array}{l}\text { Confirmed cases } \\
\text { performed tests* }(\%)\end{array}$ & $24.50 \%$ & $22.81 \%$ & $79.77 \%$ \\
\hline
\end{tabular}

Note: all the * data were based in the last week of analysis in each group (Report from Dec 23, 2020, from the NJC Portal and Report N43 Dec 20-26, 2020 from the Ministry of Health). Source: Authors.

Table 2. Paraná: Epidemiological Data of Covid-19 in the Prison System and General Population in 2020.

\begin{tabular}{|c|c|c|c|c|c|c|}
\hline & \multicolumn{2}{|c|}{ Population Deprived of Liberty } & \multicolumn{2}{|c|}{ Prison Staff } & \multicolumn{2}{|c|}{ General Population } \\
\hline & $\%$ & $\mathrm{n} / 1,000$ & $\%$ & $\mathrm{n} / 1,000$ & $\%$ & $\mathrm{n} / 1,000$ \\
\hline Confirmed Cases* & 10.02 & 100.22 & 16.64 & 166.36 & 3.50 & 35.01 \\
\hline Deaths* & 0.24 & 2.38 & 0.37 & 3.67 & 1.91 & 19.13 \\
\hline Covid-19 Mortality* & 0.02 & 0.2 & 0.06 & 0.6 & 0.07 & 0.7 \\
\hline \multicolumn{7}{|l|}{ Testing } \\
\hline Performed tests* (n) & \multicolumn{2}{|c|}{2,403} & \multicolumn{2}{|c|}{1,408} & \multicolumn{2}{|c|}{$1,452,171$} \\
\hline Tests / population* $(\%)$ & \multicolumn{2}{|c|}{$8.19 \%$} & \multicolumn{2}{|c|}{$42.98 \%$} & \multicolumn{2}{|c|}{$12.70 \%$} \\
\hline $\begin{array}{l}\text { Confirmed cases } \\
\text { performed tests* }(\%)\end{array}$ & \multicolumn{2}{|c|}{$122.43 \%$} & \multicolumn{2}{|c|}{$38.71 \%$} & \multicolumn{2}{|c|}{$27.56 \%$} \\
\hline
\end{tabular}

Note: all the * data were based in the last week of analysis in each group (Report from Dec 23, 2020, from the NJC Portal and Report N43 Dec 20-26, 2020 from the Ministry of Health). Source: Authors.

Regarding the pandemic evolution from June to December, it was observed that the cumulative number of confirmed cases was proportionally higher in the prison system populations compared to the general population. Inside the prison system, the mentioned proportion was higher between the staff than the PDL (Figures 1 and 2). 
Figure 1. Brazil: Confirmed Cases of Covid-19 in the Population of Brazilian Prison System in 2020.

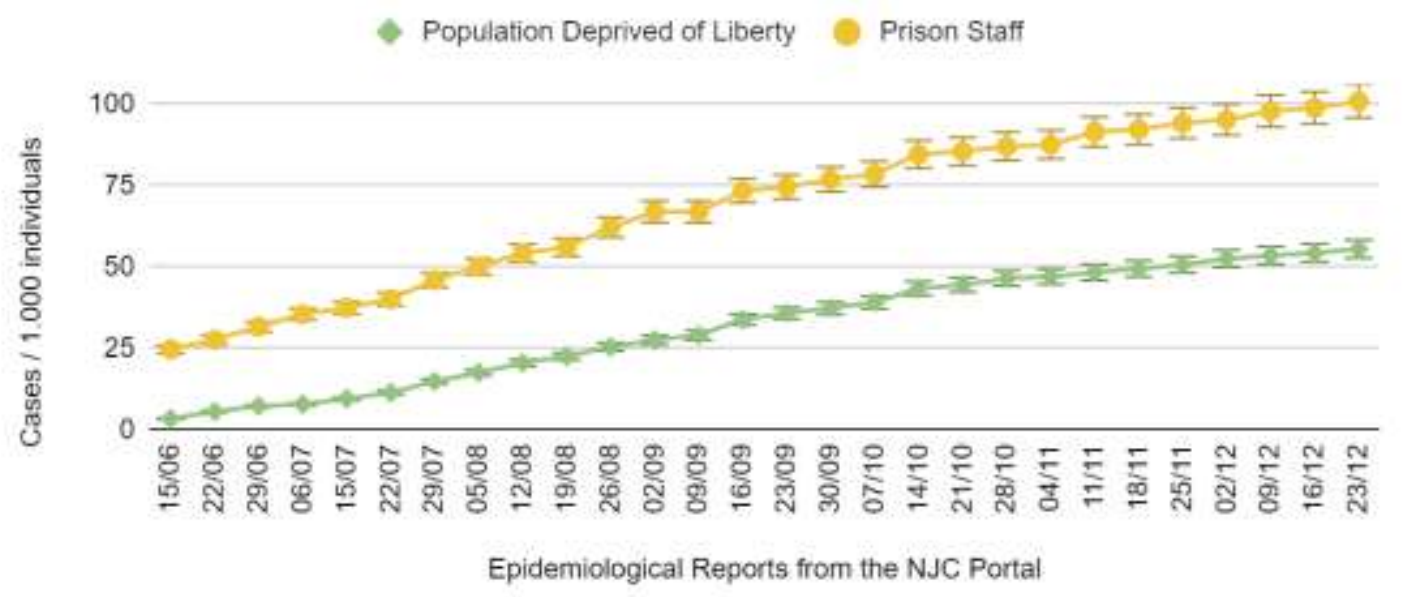

Source: Authors (2021).

Figure 2. Brazil: Confirmed Cases Of Covid-19 In The Brazilian Population In 2020.

100

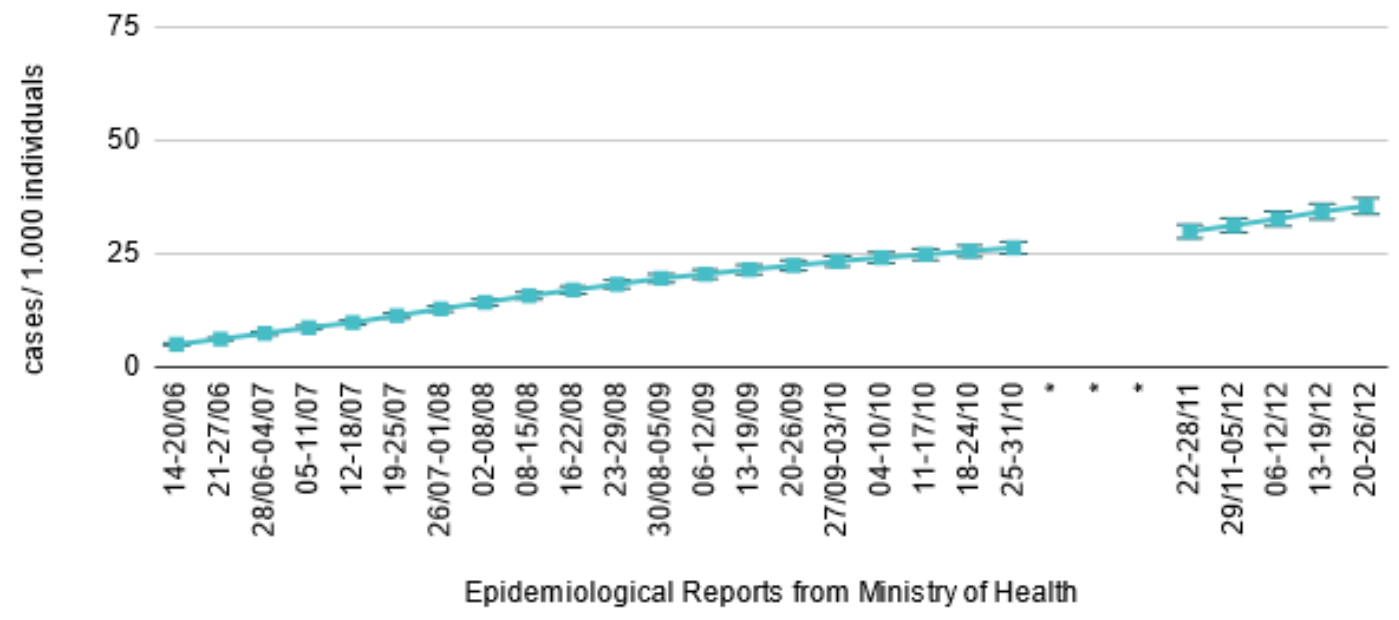

Source: Authors (2021).

Finally, a statistical analysis of the accumulated frequencies of confirmed cases of Covid-19 in the studied populations through Independence Qui-Square Test was performed (Table3). 
Table 3. Independence Qui-Square Test Between the Studied Groups.

\begin{tabular}{|c|c|c|c|c|}
\hline & Pearson $\mathrm{X}^{2}$ & $\mathbf{R R}$ & CI 95\% & \\
\hline \multicolumn{5}{|l|}{ Brazil } \\
\hline PDL x General Population & 8806.984 & 1.594 & $1.578-1.610$ & $\mathrm{p}=0.000$ \\
\hline $\begin{array}{l}\text { Prison Staff } \mathrm{x} \text { General } \\
\text { Population }\end{array}$ & 15842.354 & 3.043 & $2.988-3.099$ & $\mathrm{p}=0.000$ \\
\hline \multicolumn{5}{|l|}{ Paraná } \\
\hline PDL x General Population & 3669.212 & 3.055 & $2.941-3.173$ & $\mathrm{p}=0.000$ \\
\hline $\begin{array}{l}\text { Prison Staff } \mathrm{x} \text { General } \\
\text { Population }\end{array}$ & 1670.893 & 5.495 & $5.012-6.024$ & $\mathrm{p}=0.000$ \\
\hline
\end{tabular}

Source: Authors (2021).

The analysis showed a statistically significative association between the liberty situation (PDL, prison staff or general population) and the number of Covid-19 confirmed cases, when compared two by two: Brazilian PDL x General Brazilian Population; Paraná PDL x General Paraná Population; Brazilian Prison Staff x General Brazil Population; and Paraná Prison Staff x General Paraná Population.

\section{Discussion}

In the present study we found higher Covid-19 rates among prison staff and PDL than in Brazil and Parana populations. Prison staff presented a relative risk of 3.043 (CI 95\% 2.988 - 3.099) when compared to Brazil population. Among PDL, the relative risk was 1.594 (CI 95\% 1.578 - 1.610). This pattern was also found in the state analysis, with even bigger differences: relative risk of 5.495 (CI 95\% 5.012 - 6.024) for prison staff and of 3.055 (CI 95\% 2.941 - 3.173) for PDL.

Similar results were found in a study of Massachusetts jails and prisons (Jiménez, et al., 2020). The infection rate in PDL was 2.91 times higher than in the Massachusetts population and 4.8 times higher than in the United States (US) population. Another study found that Covid-19 rate in the PDL is 5.5 times higher than in the US population (Saloner, et al., 2020).

However, in our study, we found that PDL and prison staff had lower mortality and lethality rates than the general population (in both state and country). This result is different from the current literature. An American study found that PDL had higher mortality rate and more severe cases of Covid-19, once demographic corrections were made (Saloner, et al., 2020). A limitation of our study is that we were not able to perform demographic corrections. This can distort the interpretation of data, given that the young population (up to 29 years old) represents 55\% of the PDL in Brazil, whereas this proportion is 18\% in the general population (Ministério da Saúde \& Ministério da Justiça, 2014).

An interesting finding is that the proportion of prison staff tested is higher than the proportion of PDL. $44.24 \%$ of the national prison staff were tested versus 22,68\% of the PDL. In the state of Paraná, the numbers found were $42.98 \%$ for prison staff and 9,19\% for PDL. This finding points to the need to increase testing in the PDL and may explain why there was a higher rate of Covid-19 cases among prison staff than in the PDL.

In addition to protecting the PDL, health initiatives in jails and prisons can decrease the transmission of Covid-19 outside these institutions. The circulation of penitentiary agents, visitors, workers and released prisoners can help spreading the virus. An American study found that 15.9\% of the Covid-19 cases in Chicago in April 2020 were associated with the local prison and the release of prisoners (Reinhart \& Chen, 2020).

Measures against Covid-19 in prisons must be based in three premises: the entrance of the virus should be delayed as much as possible; if already in circulation, the transmission should be controlled; and prisons should be prepared to manage cases of Covid-19 disease (Akiyama; Spaulding \& Rich, 2020). 
The control of transmission in prisons is a challenge once social distancing, one of the pilar measures for Covid-19 prevention, is frequently impracticable due to factors such as overcrowding, lack of ventilated environments, and shared bathrooms and cells (Meyer, et al., 2020). In Brazil, for instance, 79\% of the prisons are overcrowded (DEPEN, 2017).

The CNJ developed on March 17, 2020 the measures against Covid-19 adopted by Brazilian prisons (CNJ, 2020). However, they were implemented by the states' governments, so there were differences between states (Prison Insider, 2021).

In the first monitoring report of the $\mathrm{CNJ}$ recommendations, $62 \%$ of the states had implemented the release of pretrial detainees and 50\% had altered closed system sentences, by adopting house arrest, for example. The most adopted preventive measures were hygiene of the common spaces and implementation of educational activities (done by 22 states). Eighty-one percent of the states suspended visits (Conselho Nacional de Justiça, Programa das Nações Unidas para o Desenvolvimento \& Departamento Penitenciário Nacional, 2020).

It is important that the decision to release prisoners is accompanied by public policies against social inequality (Carvalho; Santos \& Santos, 2020). As well as social distancing measures should be done along with psychological counselling and the adoption of video calls to replace in-person visits (Akiyama; Spaulding \& Rich, 2020) (Robinson; Heyman-Kantor \& Angelotta, 2020).

Several limitations are apparent in this study. First, demographic data were not available on the public sources consulted, so we were not able to perform the proper demographic corrections to compare the populations studied (PDL, prison staff and general population). Second, we did not take demographic variations (due to other causes mortality, prison release and arrival of new prisoners, for example) into account once we did not have access to this information. Finally, our study relied on information released by the $\mathrm{CNJ}$, therefore data inconsistencies are possible, even though this is the most reliable public source on PDL available.

\section{Conclusion}

In conclusion, this study's findings suggest that there is a highest rate of Covid-19 cases in Brazil's and Paraná's prisons then in the general population. Therefore, it is necessary to increase testing in prisons and to adopt preventive measures, which will not only protect this at-risk population but will also avoid the spread of the virus to the outside community.

\section{References}

Akiyama, M. J., Spaulding, A. C., \& Rich, J. D. (2020). Flattening the Curve for Incarcerated Populations - Covid-19 in Jails and Prisons. The New England journal of medicine, 382(22), 2075-2077. https://doi.org/10.1056/NEJMp2005687

Barnert E. S. (2020). COVID-19 and Youth Impacted by Juvenile and Adult Criminal Justice Systems. Pediatrics, 146(2), e20201299. https://doi.org/10.1542/peds.2020-1299.

Departamento Penitenciário Nacional (DEPEN). (2017). INFOPEN. http://depen.gov.br/DEPEN/depen/sisdepen/infopen

Carvalho, S. G., Santos, A., \& Santos, I. M. (2020). The pandemic in prison: interventions and overisolation. A pandemia no cárcere: intervenções no superisolamento. Ciencia \& saude coletiva, 25(9), 3493-3502. https://doi.org/10.1590/1413-81232020259.15682020.

Conselho Nacional de Justiça (CNJ). (2020). Recomendação Nº 62, de 17 de Março de 2020. CNJ. https://www.cnj.jus.br/wp-content/uploads/2020/03/62Recomenda\%C3\%A7\%C3\%A3o.pdf.

Conselho Nacional de Justiça, Programa das Nações Unidas para o Desenvolvimento \& Departamento Penitenciário Nacional. (2020). Relatório de Monitoramento da COVID-19 e da Recomendação 62/CNJ nos Sistemas Penitenciário e de Medidas Socioeducativas I. CNJ. https://www.cnj.jus.br/wpcontent/uploads/2020/09/Relat_Form_Monitoramento_I.pdf.

Conselho Nacional do Ministério Público (CNMP). (2018). A Visão do Ministério Público sobre o Sistema Prisional Brasileiro. https://www.cnmp.mp.br/portal/publicacoes/11797-avisaodosistemaprisionalbrasileiro.

Conselho Nacional do Ministério Público (CNMP). (2019). Sistema Prisional em Números. https://www.cnmp.mp.br/portal/relatoriosbi/sistema-prisional-emnumeros. 
Jiménez, M. C., Cowger, T. L., Simon, L. E., Behn, M., Cassarino, N., \& Bassett, M. T. (2020). Epidemiology of COVID-19 Among Incarcerated Individuals and Staff in Massachusetts Jails and Prisons. JAMA network open, 3(8), e2018851. https://doi.org/10.1001/jamanetworkopen.2020.18851.

Khan, M., Adil, S. F., Alkhathlan, H. Z., Tahir, M. N., Saif, S., Khan, M., \& Khan, S. T. (2020). COVID-19: A Global Challenge with Old History, Epidemiology and Progress So Far. Molecules (Basel, Switzerland), 26(1), 39. https://doi.org/10.3390/molecules26010039

Meyer, J. P., Franco-Paredes, C., Parmar, P., Yasin, F., \& Gartland, M. (2020). COVID-19 and the coming epidemic in US immigration detention centres. The Lancet. Infectious diseases, 20(6), 646-648. https://doi.org/10.1016/S1473-3099(20)30295-4

Ministério da Saúde, Ministério da Justiça. (2014). Política nacional de atenção integral à saúde das pessoas privadas de liberdade no sistema prisional. Brasília: Ministério da Saúde.

Njuguna, H., Wallace, M., Simonson, S., Tobolowsky, F. A., James, A. E., Bordelon, K., Fukunaga, R., Gold, J., Wortham, J., Sokol, T., Haydel, D., Tran, H., Kim, K., Fisher, K. A., Marlow, M., Tate, J. E., Doshi, R. H., \& Curran, K. G. (2020). Serial Laboratory Testing for SARS-CoV-2 Infection Among Incarcerated and Detained Persons in a Correctional and Detention Facility - Louisiana, April-May 2020. MMWR. Morbidity and mortality weekly report, 69(26), 836-840. https://doi.org/10.15585/mmwr.mm6926e2

Prison Insider. (2021). Brazil: managing uncertainty. https://www.prison-insider.com/en/articles/brazil-managing-uncertainty.

Reinhart, E., \& Chen, D. L. (2020). Incarceration And Its Disseminations: COVID-19 Pandemic Lessons From Chicago's Cook County Jail. Health affairs (Project Hope), 39(8), 1412-1418. https://doi.org/10.1377/hlthaff.2020.00652

Robinson, L. K., Heyman-Kantor, R., \& Angelotta, C. (2020). Strategies Mitigating the Impact of the COVID-19 Pandemic on Incarcerated Populations. American journal of public health, 110(8), 1135-1136. https://doi.org/10.2105/AJPH.2020.305754.

Saloner, B., Parish, K., Ward, J. A., DiLaura, G., \& Dolovich, S. (2020). COVID-19 Cases and Deaths in Federal and State Prisons. JAMA, 324(6), 602-603. https://doi.org/10.1001/jama.2020.12528

Sylverken, A., El-Duah, P., Owusu M., Yeboah, R., Kwarteng, A., Oforo, L., Gorman, R., Obiri-Danso, K., \& Owuso-Dabo, E. (2019). Burden of Respiratory Viral Infections Among Inmates of a Ghanaian Prison. Preprint. https://doi.org/10.21203/rs.2.14139/v1.

The Legal Aid Society. (2020). COVID-19 infection tracking in NYC jails. https://legalaidnyc.org/covid-19-infection-trackingin-nyc-jails/.

Wang, E. A., Zenilman, J., \& Brinkley-Rubinstein, L. (2020). Ethical Considerations for COVID-19 Vaccine Trials in Correctional Facilities. JAMA, 324(11), 1031-1032. https://doi.org/10.1001/jama.2020.15589.

World Prison Brief (WPB). (2021). Highest to Lowest - Occupancy level (based on official capacity). https://www.prisonstudies.org/highest-tolowest/occupancy-level?-field_region_taxonomy_tid=All. 